\title{
Can agriculture and conservation be compatible in a coastal wetland? Balancing stakeholders' narratives and interactions in the management of El Hondo Natural Park, Spain
}

\author{
Sandra Ricart ${ }^{1,2}$ - Antonio M. Rico-Amorós ${ }^{1,3}(1)$ \\ Accepted: 29 September 2021 / Published online: 5 October 2021 \\ (c) The Author(s) 2021
}

\begin{abstract}
Coastal wetlands are among the most productive and valuable ecosystems worldwide, although one of the main factors affecting their survival is the coexistence between agriculture and conservation. This paper analyses the complex balance between agriculture and conservation coexistence in El Hondo Natural Park (Alicante, Spain) coastal wetland by examining stakeholders' narratives, perceptions, and interactions. The aim is to highlight the concurrence between socio-economic progress and socio-environmental justice perspectives by identifying those driving factors motivating stakeholders' conflicts while expanding stakeholders' behaviour and interaction when discussing the current and future management of this socioecological system. Data were collected between April and June 2019 from semi-structured interviews and questionnaires to river basin authorities, regional governments, municipalities, irrigation communities, union farms, regional and local ecologist groups, and social movements; and scrutinized through qualitative data analysis and descriptive statistics. Stakeholders discussed the main driving factors identified through the local newspapers to motivating current conflicts and confronting perspectives in El Hondo Natural Park: (1) the origin and evolution of the coastal wetland, (2) the provision and value of ecosystem services, (3) the management of water scarcity and water quality standards, (4) the guarantee and management of public and private investment, and (5) consequences of a natural park declaration. Likewise, the triple-loop analysis of stakeholders' representativeness, relevance and collaboration highlighted examples of stakeholders' underrepresentation and power imbalance, a negative assessment of the stakeholders' actions, and how agreements are based on both stakeholders' predisposition to collaborate and affinity.
\end{abstract}

Keywords Coastal wetland $\cdot$ Agriculture $\cdot$ Conservation $\cdot$ Decision-making process $\cdot$ El Hondo Natural Park $\cdot$ Spain

Sandra Ricart

sandra.ricart@ua.es

Antonio M. Rico-Amorós

am.rico@ua.es

1 Interuniversity Institute of Geography, University of Alicante, University institutes building 37, Carretera de San Vicente del Raspeig, s/n, Sant Vicent del Raspeig, 03690 Alicante, Spain

2 Environmental Intelligence for Global Change Lab. Department of Electronics, Information and Bioengineering, Politecnico di Milano, Via Ponzio 34/5, 20133 Milan, Italy

3 Department of Regional Geographic Analysis and Physical Geography, University of Alicante, Carretera de San Vicente del Raspeig, s/n, Sant Vicent del Raspeig, 03690 Alicante, Spain

\section{Abbreviations \\ SCI Site of community importance \\ SPA Special protection area for birds}

\section{Introduction}

Coastal wetlands are unique and complex socio-ecological systems composed of interacting biophysical and social processes (Speake et al. 2020). They are located in transitional zones between terrestrial and aquatic systems and represent about 7\% of global wetlands' area (Davidson 2014), although two-thirds of their extension disappeared in the twentieth century due to human-enforced adaptation. Moreover, it is projected that their loss and environmental degradation will increase in the following years ( $\mathrm{Li}$ et al. 2018). These habitats play a significant role in the provision of ecosystem services and functions, 
including carbon sequestration (Craft et al. 2018), flood and stormwater storage (Janse et al. 2019), water regulation and filtration (Fennessy and Craft 2011), nutrient retention (Hopkins et al. 2018), while being essential buffers in the landscape's hydrology acting as a harbor for many endemic species (Costanza et al. 2014). However, wetlands are often considered wastelands, which should be transformed into "useful" (human) systems (e.g., by agriculture, forestry, husbandry, hunting, or fishing) (Junk et al. 2013). Likewise, their significant aesthetic values can also be aligned with education, recreation, and ecotourism activities (Vidal-Giménez and Ruiz-Mas 2020).

As socio-ecological systems, coastal wetlands cover different and sometimes conflicting water resources supply and management expectations that reflect environmental, economic, social, cultural, and political interests (Everard 2019). Therefore, coastal wetlands management has been discussed considering a dual narrative able to highlight (1) socio-economic progress, based on private benefits from water and land management, or (2) socio-environmental justice, recognizing non-economic values and common goods and based on public participation (Svarstad and Benjaminsen 2020; Prieto-López et al. 2021). This dual interpretation of coastal wetlands has been used to justify their consideration as 'hydrosocial territories': spatial configurations in which humans and water co-construct themselves based upon complex interactions of contrasting narratives and local knowledge concerning the use, control, and management of land and water resources (Schmidt 2014; Boelens et al. 2016; Wilfong and Pavao-Zuckerman 2020). Consequently, water is considered a materially disputed resource in which needs, rights, obligations, and privileges across various social sectors coexist (Voyer et al. 2017), moving from contested imaginaries to materialized conflicts (Ricart et al. 2019).

Agriculture has been the activity that has mostly transformed coastal wetlands (e.g., up to $50 \%$ of the world's coastal wetlands were reclaimed for agriculture and aquaculture activities in the last century) (Verhoeven and Setter 2010; Ragavan et al. 2020). This transformation tends to generate conflicts between agriculture and conservation, in which in situ and external interactions can be distinguished, although they may coincide in time (FAO 2008). On the one side, in situ interactions occur where there is a direct agricultural intervention within wetlands (e.g., drainage works, over-exploitation of groundwater resources, crop production, aquaculture, "artificially" constructed wetland environments such as fish ponds, pollution, invasive plant and animal species, or disturbance of breeding, migration, and feeding patterns of wetland fauna). On the other side, external interactions appear when the effects of external -upstream, downstream or peripheral- agricultural activities affect the wetland (e.g., river regulation, water transfers, land reclamation, soil erosion, sediment retention and deposition, or saline influxes) (Kingsford et al. 2016; Zou et al. 2018). Therefore, coastal wetlands management is seen as a complex and continuous struggle over in-situ and external interactions in which agriculture and conservation coexistence tend to be analysed through a set of stakeholders' storylines (Silber-Coats 2017).

This paper analyses the complex balance between agriculture and conservation coexistence in El Hondo Natural Park (Spain) by examining stakeholders' narratives, perceptions, and interactions. The aim is to highlight the concurrence between socio-economic progress and socio-environmental justice perspectives by identifying those driving factors motivating stakeholders' conflicts while expanding stakeholders' behaviour and interaction when discussing the current and future management of this socio-ecological system.

\section{Case study}

El Hondo Natural Park is situated in Alicante, Spain's SouthEast (N 38.202250; W 0.757072) (López-Pomares et al. 2009). With an extension of $2387 \mathrm{Ha}$, this coastal wetland is one of the elements that survive from Elche's original Albufera, reduced in its size by drainage works carried out in the eighteenth century. However, the main change started in 1923 when the Riegos de Levante Left Margin irrigation community built two large interconnected ponds (Poniente and Levante) of freshwater taken from the Segura River's mouth, occupying half of the park with a capacity of 16 $\mathrm{Hm}^{3}$ (Fig. 1). Both ponds serve as water reservoirs to irrigate about 31,600 Ha distributed outside the natural park's current limits (Fig. 2). Furthermore, five main canals internally connect about ten smaller hunting/fishing ponds and four ponds dedicated to ecological conservation to the two main ponds (Melgarejo-Moreno et al. 2018).

Agriculture occupies about half of the total extension of El Hondo Natural Park and is limited to traditional crops of pomegranates, orchards, and palm tree nurseries. In addition to agricultural use, both ponds have been historically used for fishing and hunting. However, since its declaration as a natural park in 1994, fishing was limited to sport fishing and water birds hunting has been progressively restricted. This last restriction affected the economic activity of small landowners, but not the Riegos de Levante Left Margin irrigation community who has been receiving economic compensation from the regional government (Ruiz 2014). During the year, the natural park houses more than 20,000 wintering water birds from 179 species (Martín-Cantarino 2009), running as a wintering ground (e.g., Eurasian bittern, spoonbill, flamingo) and as a nesting habitat (e.g., little egret, cattle egret, night heron, squacco heron, purple heron, marbled teal, and 


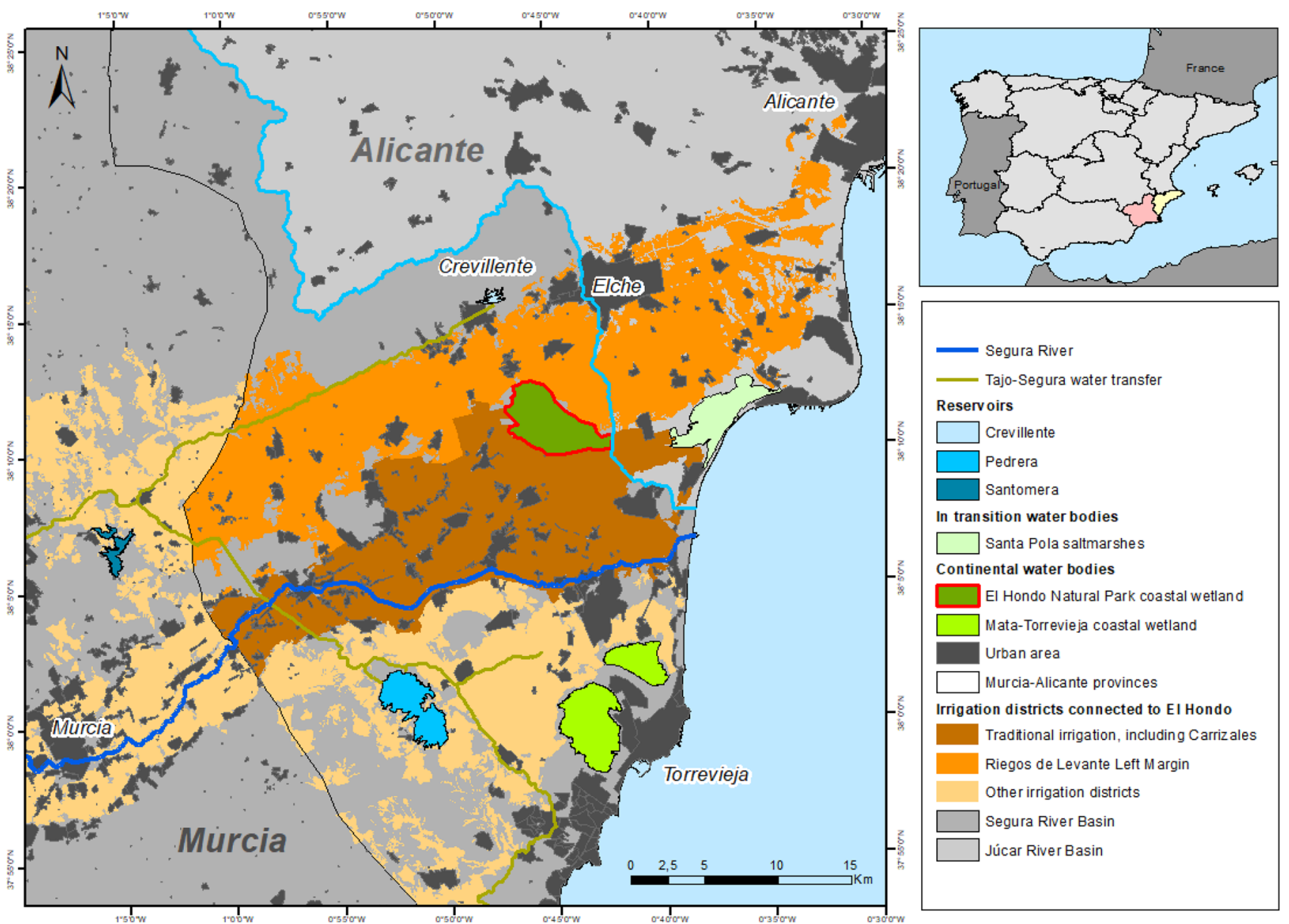

Fig. 1 Location of El Hondo Natural Park

white-headed duck). The abundance and diversity of birds contributed to the classification of the natural park as a wetland of international importance (Canales et al. 2012), besides being internationally recognized by the Ramsar agreement and included as a Special Protection Area for Birds (SPA) and Site of Community Importance (SCI). In March 2020, the SPA was extended to almost double its surface (until the $3900 \mathrm{Ha}$ ) by including the Carrizales Agricultural Natural Park's surrounding surface.

In parallel to the conservation issue, the natural park's recreational and educational uses were promoted by the city councils of Elche and Crevillente and the Natural Park Advisory Board. According to the Advisory plan of the natural park, the number of visitors has been doubled in the last ten years until receiving 26,519 visitors in 2019. Two types of visitors can be distinguished. On one side, the foreign visitors usually proceed from northern Europe motivated by birds watching activities and ornithological, fauna, botanical, or cultural content routes linked to popular ethnology. Most of these activities are promoted by local ecologist groups in collaboration with some farmers and occur in two specific seasonal periods: from February to May (birds' nidification) and in September (birds' migration). On the other side, residents from nearby towns frequent the space on weekends (e.g., bicycle routes), while during the week, school groups visit the natural park.

\section{Conceptual framework}

The hydrosocial cycle approach examines key stakeholders' physical and socio-political discourses on water resources, identifying end-users contradictions (Reed et al. 2009). This framework has been useful to evaluate the impact of unequal power relations from a social, political, economic, cultural, and territorial point of view regarding water resources use and management, but also considering the role of water infrastructures and unequal water benefits and social impacts (Linton and Budds 2014). The literature on this topic considers that exploring stakeholders' local knowledge and perception is essential for their understanding (Guaita-García et al. 2021). Stakeholder participation is seen as a critical tool for 


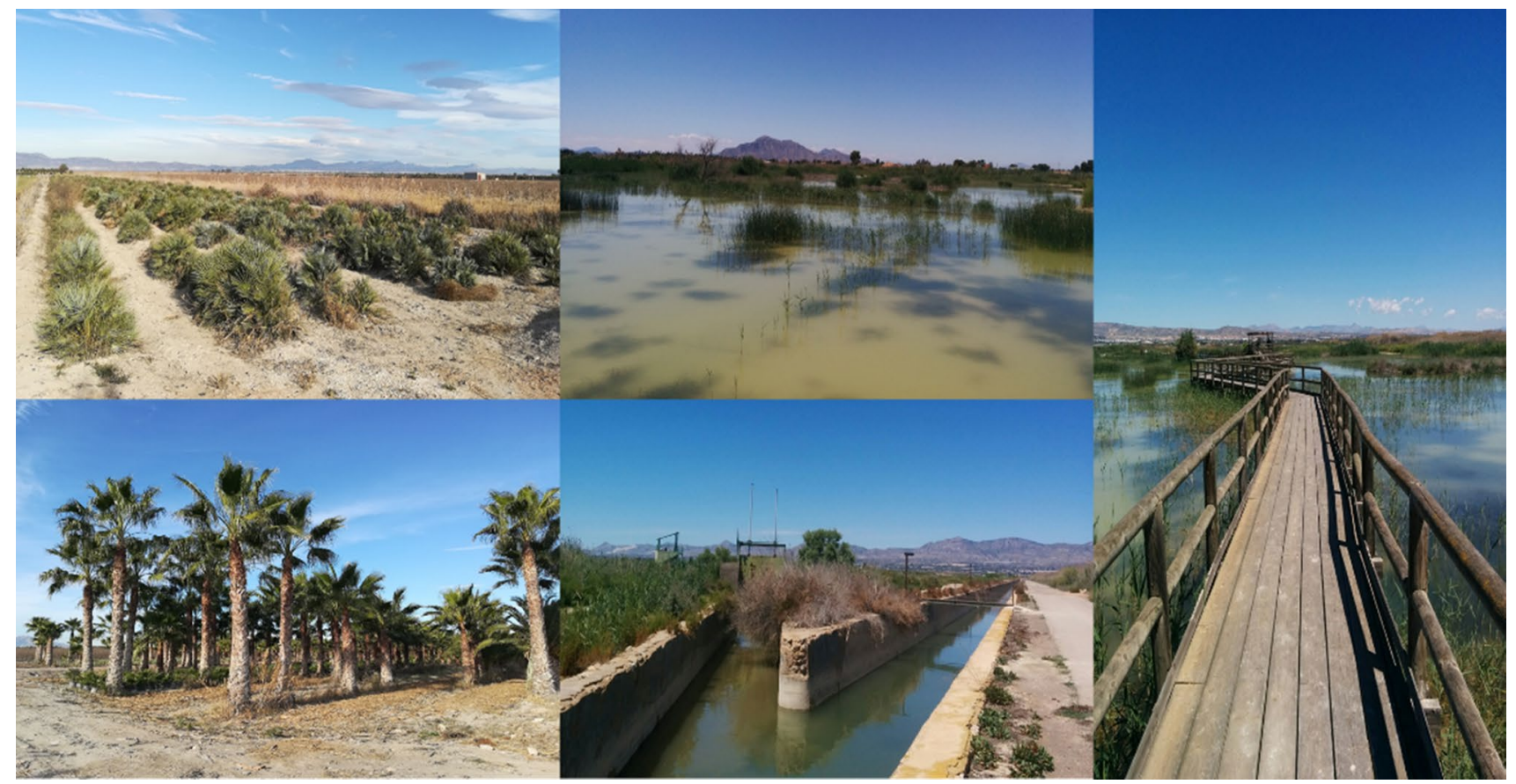

Fig. 2 Main water uses in El Hondo Natural Park: environmental, agricultural and recreational

conflict resolution (Godden and Ison 2019) because stakeholders' engagement incorporates a distinctly constructivist stance, focusing upon the meanings and values that individuals and communities attach to their physical surroundings and potential environmental harms, and the tactics and discourses mobilized to engage those meanings and values (Fisher et al. 2020).

Stakeholders include communities, interest groups, discourse coalitions, organizations, social constituencies, environmental and social defenders, or individual people (Colvin et al. 2020; Scheidel et al. 2020), but also any individual or group living within the site's influence or likely to influence the site's management (Ramsar Convention Secretariat 2010) or actors dependent on the site for their livelihood (Bryson 2004; Colvin et al. 2016). Various functions of stakeholder participation are discussed in the literature, moving from opportunities to weaknesses. The first one includes exchanging knowledge and experiences, increasing public acceptance, and reducing litigation (Ruiz-Villaverde and García-Rubio 2017). The second comprises frustration, latent or new conflicts, lack of representation, and power or influence asymmetries -considering 'power' as the ability to influence others and distinguishing between 'power to' and 'power over' options (Lunenburg 2012; Pahl-Wostl et al. 2020; Woldesenbet 2020).

Stakeholder analysis and water governance have usually been applied to studies on environmental justice and conflicts affecting vulnerable populations, such as informal settlements, indigenous communities, racial segregation, and popular movements (Lombard and Rakodi 2016; Manosalvas et al. 2021). However, asymmetrical power relationships and human-nature conflicts are global and replicable phenomena, notably when they are motivated by water infrastructure construction, ecosystem degradation, or competing water interests (Ferguson et al. 2017; García et al. 2020; Stepanova et al. 2020; Prieto-López et al. 2021; Shah et al. 2021). Therefore, stakeholder narratives can be complemented by new conceptual and methodological issues that synthesize individual and collective stakeholders' behaviour (Wesselink et al. 2016). These issues should consider that (1) water and society make and remake each other over space and time, being changement and learning part of the process (Yonariza et al. 2019), and (2) conflicts are never socially or ecologically neutral, as their dynamics and impacts are not homogenous (Ricart 2020).

Commonly, learnings from stakeholder analysis suggest a set of qualitative analysis tools, including social network analysis or analysis through Strengths, weaknesses, opportunities and threats (SWOT) to evaluate stakeholders' interactions in a specific area of interest (Lienert et al. 2013; Rambaree et al. 2021). In this research, we try to go one step further to understand stakeholders' behaviour by developing a conceptual triple-loop analysis on governance to simplify how stakeholders' perception and interaction could be analysed: representativeness (to be), relevance (to do), and collaboration (to share). 'Representativeness' is a self-evaluation process about being (or not) part of the decision-making processes, the level of involvement, and the reasons for 
feeling (un)represented. 'Relevance' includes self-evaluation and external evaluation about stakeholders' roles, functions, and actions, contrasting theoretical empowerment (importance) with practical empowerment (influence). 'Collaboration' deepens on current and potential agreements among stakeholders, their typology, and the willingness and barriers to agreement.

\section{Material and methods}

\section{Data collection}

Face-to-face semi-structured interviews and questionnaires to 15 stakeholders have been conducted between April and June 2019. Stakeholders have been identified by key informants and local experts' feedback starting from the list of the members of the Natural Park Advisory Board and focusing on the agriculture-conservation narratives (Table 1). The selection followed the criteria expressed by Colvin et al. (2016) ('actors dependent on the site for their livelihood') and the Ramsar Convention Secretariat (2010) ('any individual or group likely to influence the site's management'). Stakeholders have been organized into three groups: government officials (regional government, municipalities, and river basin authority), the agricultural sector (irrigation communities and union farms), and socioenvironmental defenders (local ecologist groups and social movements).

Each actor was previously informed about the research and contacted by telephone or email to schedule the interview day. An interview guide was used following the standard tenets of discursive analysis (Reed et al. 2009). The guide was organized into different topics regarding the present and the future of the natural park: (1) origin, (2) ecosystem services, (3) water scarcity and quality standards, (4) investment, and (5) natural park declaration. Interviews were undertaken in a place of convenience for the interviewees, typically in their workplace. These topics have been identified as the main driving factors explaining the nature of stakeholders' interaction, discussion, and conflict according to the information published in the last ten years in two local newspapers (Diario Información and Diario Alicante Plaza) and also collected in stakeholders' websites. Each interview was conducted in Spanish or Catalan as the native language of the interviewees and was between $40 \mathrm{~min}$ and two hours in duration. All interviews are digitally recorded and transcribed.

After the interview, each actor answered a questionnaire adapted from Ricart and Gandolfi (2017) to deepen collaborative governance through structured information about stakeholders' roles, actions, and alliances when managing the natural park. The questionnaire contained
11 questions that have been organized into three sections: (1) Representativeness (five questions about stakeholders' involvement and roles during decision-making processes); (2) Relevance (three questions about self and external assessment of stakeholders' functions and actions), and (3) Collaboration (three questions about current and potential agreements among stakeholders). Closed-ended questions included single answers based on a Likert scale of five points (+ 'Do not know/No answer' option) or multiplechoice options. In addition, a section to expand the reasons for selecting an answer option has been provided for each question. Data collection has been triangulated following the recent works from Natow (2020) and Campbell et al. (2020), in which have been considered (1) multiple data sources containing different perspectives (from different stakeholders' groups), and (2) complementary qualitative methods and sources (including the interview and the questionnaire but also research observation by consulting the local newspapers and field notes).

\section{Data analysis}

Interviews were coded by the first author using the MaxQDA ${ }^{\circledR}$ Analytics Pro 2018 edition software. Four interviews (26.7\% of the total) were coded a second time (two months after the first coding process) by the first author to establish intra-rater reliability (degree of agreement between different measurements done by the same person). Almost perfect agreement intra-rater reliability was achieved for both interviewer' utterances (Cohens' $\mathrm{k}=0.85, \mathrm{p}<0.001 ; 94.2 \%$ of agreement). Both inductive and deductive research have been applied when coding to avoid testing pre-conceived hypotheses instead of allowing the theory to emerge from the raw data's content (transcribed interviews). Quotations (the shortest part of a text where the basic meaning could be understood without reading a longer part of the text) have been handcoded and grouped into main categories of topics (Scott et al. 2020). Coded quotations frequency and code coverage have been calculated, and main narratives have been highlighted.

Furthermore, the Jaccard Similarity Index (JS), a wellknown statistic coefficient used for gauging the (dis)similarity of sample sets (two underlying text excerpts), has been applied (Al-Anazi et al. 2016). In this study, the JS was used to compare stakeholders' narratives through the number of shared codes with the total number of codes to be potentially shared, ranging from 0 (entirely dissimilar) to 1 (completely similar). In parallel, the content of the questionnaire has been analysed through descriptive statistics. Finally, the nature and type of interaction between stakeholders have been highlighted by defining 
Table 1 Stakeholders' categorization and description

\begin{tabular}{lll}
\hline Stakeholder group & Stakeholder name \\
\hline Government officials & Regional & Segura River Basin Authority
\end{tabular}

Natural Park Advisory Board

Local

Elche city council

Crevillente city council

Agricultural sector

Young Farmers Agrarian Association

Union of Farmers and Livestock cultural Natural Park
Description and function

Public autonomous organization assigned to the Ministry of the Ecological Transition. Its role is to manage the Tajo-Segura water transfer, conciliate water demands, protect the environment, and ensure the water quality standards of the water bodies such as El Hondo Natural Park

Public autonomous organization assigned to the General Directorate for the Natural Environment of the Generalitat Valenciana (regional government) to ensure multifunctional activities in El Hondo Natural Park

Municipality of 234,765 inhabitants (2020). $52.21 \%(1246 \mathrm{Ha})$ of the extension of El Hondo Natural Park is within its municipal limit. It promotes recreational activities for visitors

Municipality of 29,536 inhabitants (2020). $47.79 \%(1141 \mathrm{Ha})$ of the extension of El Hondo Natural Park is within its municipal limit. It promotes recreational activities for visitors

Public law corporation formed by eight minor irrigation communities and more than 22,000 farmers. It is the owner of the two ponds built in El Hondo Natural Park. It is the beneficiary of a water concession of $77 \mathrm{Hm}^{3}$ from the Tajo-Segura river water transfer

Carrizales irrigation community and Agri-

Public law corporation comprised of 400 farmers and promoter of the agricultural natural park with an extension of $1301 \mathrm{Ha}$, acting as an agro-ecological corridor that vertebrates and units both surrounding natural parks: El Hondo and the Salinas de Santa Pola

Union farm founded in 1980. Among their associated members (rainfed farmers and irrigators) there are irrigators using water resources from El Hondo Natural Park

Union farm founded in 1976. Among there associated members (rainfed farmers and irrigators), there are irrigators using water resources from El Hondo Natural Park when other water sources are not available 
Table 1 (continued)

Stakeholder group

Socioenvironmental defenders Environment
Stakeholder name

SEO/BirdLife

Southeast Naturalists Association

Friends of the Wetlands of the South of Alicante

Multifunctionality Local Action Group Sur de Alicante

Vinalopó Observatory

Rural Development of the Camp d'Elx Association

Sustainable Development of Protected Natural Spaces Association
Description and function

Founded in 1954, the Spanish Ornithological Society is Spain's main bird conservation charity. Its actions are focused on the study and protection of birds, and it counts with a local action group located in Alicante, which participates in research projects with El Hondo Natural Park as a case study

Founded in 1973, making it the oldest ecological and naturalist association in Alicante and the fourth in Spain. Furthermore, it is the owner of a $4 \mathrm{Ha}$ lagoon located at the perimeter-protected zone of El Hondo Natural Park

Founded in 1995 to promote activities for the conservation, study, and dissemination of the natural and landscape values of the wetlands of southern Alicante. A custody agreement with the Carrizales irrigation community has been established to promote sustainable agricultural practices, with the aim to replicate the experience in El Hondo Natural Park in the near future

An initiative of the Rural Sustainability and Innovation Association (ASiR) for the sustainable development of the rural environment in the southern territories of Alicante. The area of action $\left(878.54 \mathrm{Km}^{2}\right)$ comprises 13 municipalities and 80 public and private entities, for which El Hondo Natural Park is a key factor for the socio-economic development of the region

Non-profit entity founded in 2012 to highlight the overexploitation of aquifers and poor water purification affecting the Vinalopó river, the most important river in the Alicante region

Composed of 32 organizations and private companies, this association promotes rural development in line with environmental requirements, as currently occurs in the Carrizales Agricultural Natural Park, and it could happen in El Hondo Natural Park

Association composed of a dozen landowners of El Hondo who are not members of the Riegos de Levante Left Margin irrigation community. They are the owners of five hunting grounds in El Hondo Natural Park, and most of them develop activities related to sport fishing 
their values, attitudes, interests, and demands regarding the natural park (Wang and Chen 2020).

\section{Results}

\section{Use and similarity between codes}

\section{Codes frequency and coverage}

Inductive coding identified 24 codes duly organized in different topics: (1) Origin, (2) Ecosystem services, (3) Water scarcity and quality standards, (4) Investment, and (5) Natural Park declaration. Face-to-face interviews' analysis collected 276 quotations, of which socioenvironmental defenders contributed with 165, while the agricultural sector and the government officials counted for 59 and 52 quotations, respectively. The majority of the quotations (59.8\%) have been associated with the investment in and declaration of the natural park, highlighting three codes: conflicts-agreements, public-private partnership, and natural park declaration, while the ecosystem services topic provided relevant background on the code environment and agriculture coexistence (Table 2 synthesize the three codes that accumulate a more significant number of quotations from interviews). Moreover, it is interesting to contrast quotations assigned to the same most used code from stakeholders with opposed narratives. For example, both Riegos de Levante Left Margin irrigation community and SEO-BirdLife provide quotations mainly assigned to the environment and agriculture coexistence code. However, the narrative "a duck has no more value than a farmer does, and vice versa" provided by the Riegos de Levante Left Margin irrigation community is refused by SEO-BirdLife because "farmer' interests have mainly legitimated the value of the wetland instead of putting in value how to ensure the empathy between the conservationist and the farmer (...), that will be the first step to ensure the same value to a duck and a farmer".

\section{Similarity}

The highest JS value occurred between the Young Farmers Agrarian Association and the Segura River Basin Authority $(\mathrm{JS}=0.71$ ), while $\mathrm{JS}>0.50$ (which means sharing, at least half of the codes) occurred internally between members of the agricultural sector (Union of Farmers and Livestock and Riegos de Levante Left Margin irrigation community) and socioenvironmental defenders, as for example between SEO-BirdLife and the Vinalopó Observatory (JS =0.58), the Vinalopó Observatory and the Sustainable Development of Protected Natural Spaces Association (JS =0.55), or SEO-BirdLife and both the Rural Development of the Camp d'Elx Association and the Sustainable Development of Protected Natural Spaces Association ( $\mathrm{JS}=0.52)$. Moreover, the lowest values of the JS could indicate dissimilar issues of concern between

Table 2 Main codes assigned to each actor

\begin{tabular}{|c|c|c|c|}
\hline Stakeholder & Code 1 & Code 2 & Code 3 \\
\hline Segura river basin authority & Origin & Conflicts - Agreements & Water quality standards \\
\hline Natural park advisory board & Future & Participation & Birds watching \\
\hline Elche city council & Information & Agricultural natural park & Public-private partnership \\
\hline Crevillente city council & Promotion & Agricultural natural park & Leisure \\
\hline $\begin{array}{l}\text { Riegos de Levante left margin irrigation } \\
\text { community }\end{array}$ & Alternative water sources & Environment and agriculture coexistence & Farmers survival \\
\hline $\begin{array}{l}\text { Carrizales irrigation community and agricul- } \\
\text { tural natural park }\end{array}$ & Agricultural natural park & Investment & Farmers survival \\
\hline Young farmers agrarian association & Conflicts - Agreements & Natural park declaration & Water supply \\
\hline Union of farmers and livestock & Origin & Environment and agriculture coexistence & Investment \\
\hline SEO-BirdLife & $\begin{array}{l}\text { Environment and agricul- } \\
\text { ture coexistence }\end{array}$ & Natural park declaration & Politics-Power \\
\hline Southeast naturalists association & Future & Public-private partnership & Investment \\
\hline $\begin{array}{l}\text { Friends of the wetlands of the south of } \\
\text { Alicante }\end{array}$ & Pollution issues & Water supply & Politics-Power \\
\hline Local action group Sur de Alicante & Promotion & Environment and agriculture coexistence & Cultural \\
\hline Vinalopó observatory & Future & Conflicts - Agreements & Water scarcity \\
\hline $\begin{array}{l}\text { Rural development of the Camp d'Elx asso- } \\
\text { ciation }\end{array}$ & Public-private partnership & Farmers survival & Participation \\
\hline $\begin{array}{l}\text { Sustainable development of protected natural } \\
\text { spaces association }\end{array}$ & Public-private partnership & Natural park declaration & Origin \\
\hline
\end{tabular}


stakeholders. In all bidirectional interactions, JS $<0.50$ means that almost half of the coded topics are not shared between any of the stakeholders. A possible explanation could be that although a topic (code) was similarly affecting different stakeholders, those stakeholders with the lowest JS values may feel unmotivated to share their concerns with the others. In this sense, it is necessary to descend to a ratio of JS $\geq 0.30$ to identify how some socioenvironmental defenders (SEO-BirdLife, Vinalopó Observatory, Rural Development of the Camp d'Elx Association, and the Sustainable Development of Protected Natural Spaces Association), Riegos de Levante Left Margin irrigation community, and the Natural Park Advisory Board can share their concerns with at least half of the interviewees. On the contrary, both the city councils and the environmental platforms are not capable of generating dialectical synergies both at the regional level (SEO-BirdLife) and with the rest of the stakeholders.

\section{Driving factors motivating stakeholders' conflict}

\section{Origin}

The starting point of the discussion between stakeholders is El Hondo Natural Park's origin as natural (wetland) or anthropic (water reservoir). While for the Riegos de Levante Left Margin irrigation community "El Hondo has the soul of a wetland but the heart of a reservoir", union farms such as the Union of Farmers and Livestock does not consider this multifunctional nature, because "El Hondo was formed from an artificial action, by not drying out part of the wetland that will be used as ponds". This argument is used by local ecologist groups to confirm the natural origin of the system, as expressed by the Southeast Naturalists Association as "only natural systems could be artificialized". However, social movements as the Vinalopó Observatory wonders how to justify the "natural" attribute of El Hondo Natural Park "when nothing is natural: water sources are artificially regulated; water resources have to be pumped; excavators build channels, and space limits are straight lines".

\section{Ecosystem services}

All the stakeholders agree with the diversity of benefits provided by El Hondo Natural Park, from provisioning (water and food) to regulating (water purification and water scarcity) and supporting (biodiversity), but also including cultural services (recreation, education, landscape, heritage). However, the coexistence between provisioning and supporting services generates tensions between the agricultural sector and socioenvironmental defenders. For example, while SEO-BirdLife and the Southeast Naturalists Association recognized the perimeter of El Hondo Natural Park as a key area for biodiversity, the Union Farmers and Livestock wonder "why biodiversity does not generate an economic benefit for the farmers who are implementing sustainable agricultural practices?". Regarding the cultural services, the agricultural sector and socioenvironmental defenders agree on El Hondo Natural Park's consideration as a factor to preserve local identity. This local identity is related to "the inheritance of the traditional agricultural practices, water management, rural heritage, and landscaping", as recognized by the Vinalopó Observatory. Moreover, the progressive restriction of hunting has increased the defence of this practice for its cultural value because "losing the culture of hunting is as serious as not having water for crops or harming the environment", as recognized by the Riegos de Levante Left Margin irrigation community. However, the Union of Farmers and Livestock consider that local identity is being lost because the agricultural sector had not been able to transmit to society the value of this hybrid system "as a witness of the experience passed down through the years". Finally, the leisure function is promoted by the Natural Park Advisory Board, although both the Crevillente and Elche city councils considered that this function has not been extensively popularized among citizens and visitors. According to the Elche city council, the reason why the leisure function is not really valued is that "although citizens generally know about El Hondo Natural Park, most people think that it cannot be visited". This fits well with the argument shared by the Southeast Naturalists Association when criticizes the accessibility restrictions imposed by the Riegos de Levante Left Margin irrigation community and how this effect the leisure function of the park, without considering that as SPA, the natural park is a common good to be shared with the public. The Riegos de Levante Left Margin irrigation community, as the owner of the natural park, argued that "although El Hondo Natural Park is open to citizens, it cannot be ignored that it is a private property, and is the owner who fixes how and when the access to the natural park could be allowed".

\section{Water scarcity and quality standards}

The Segura river suffers from semi-permanent drought periods, and stakeholders are aware of the region's water scarcity risk. To address this situation, the Elche city council considered that "actions can no longer focus on water demand, but in water supply, so the only option for addressing water scarcity will be the use of reclaimed or desalinated water". However, water scarcity "is not affecting only water supply, but water quality standards due to the high levels of salts and eutrophication, therefore, biodiversity", as recognized by SEO-BirdLife and supported by the Natural Park Advocacy Board, for who "the situation worsens in summer". The Segura River Basin Authority confirmed that the only way to ensure water quality standards was "to mix water from 
conventional and alternative water sources". The Sustainable Development of Protected Natural Spaces Association considered that addressing both water scarcity and water quality standards will require the awareness and involvement of urban society because "water flowing into El Hondo Natural Park through the Segura River comes from industrialized and urbanized environments". In this sense, the Vinalopó Observatory considered that "farmers must understand that I, as a citizen who paid the water bill, I have the right to use as much water as I can afford, so when I turn on the tap I do not consider either the water supply for the farmers or the well-being of the wetland". According to the Sustainable Development of Protected Natural Spaces Association, the only way to face water scarcity and quality standards is to understand that water is the key issue and not the citizens, farmers, or the environment because "without water, there is no life, no fish, no ducks, no gastronomy, no local agriculture, no landscape, no tourism, and no research".

\section{Investment}

The investment required to maintain the natural park (both financial and infrastructural) generates conflicting points of view between the agricultural sector and socioenvironmental defenders. The Union of Farmers and Livestock recognized that maintaining the natural park is expensive from a technical point of view but "cultural and natural values of a community must be ensured even when the cost is so high: El Hondo Natural Park should be valued not from how much cost its maintenance but for how it fulfills with socioeconomic functions and guarantee ecosystem services", while the Southeast Naturalists Association considered that "the investment granted to farmers through the Riegos de Levante Left Margin irrigation community for their conservation role should have been invested in expropriating the two ponds. That would have been the only way to really invest in conservation". SEO-BirdLife called for greater transparency of the amount of investment to El Hondo Natural Park, because "government officials do not provide enough information to audit the public investment or to know what the investment has been used for". However, the Vinalopó Observatory pointed to another source of investment, the research, because "the natural park received three LIFE projects from the European Commission: one focused on protecting wetlands, and two focused in the recovery of endangered fauna, in which local ecological groups have participated".

\section{Natural park declaration}

The natural park's declaration in 1994 also motivated opposite points of view between the agricultural sector and the socioenvironmental defenders. The Riegos de Levante Left Margin irrigation community argued that "due to this figure of protection, the regional government, who is the owner of $25 \%$ of the natural park, is imposing environmental requirements to farmers, who are the owners of the remaining $75 \%$, and this is not fair at all". In the same line, the Sustainable Development of Protected Natural Spaces Association considered that the designation of the natural park does not entail any benefit for the farmers, only restrictions because "hunting is restricted, fishing is delimited, and agriculture is not productive. If environmental and leisure functions are imposed as common goods in favour of the public interest, how can farmers survive?". This association considers that the situation responds to the fact that "El Hondo is a natural park drawn on paper, but it is artificial on the ground, so it will only survive if the regional government maintains it artificially through subsidies to the Riegos de Levante Left Margin irrigation community". For SEO-Birdlife, "when in the 90' the natural park was declared, the environmental function prevailed over the agriculture, and this situation can only generate conflicts because farmers did not feel involved in the natural park declaration discussion process".

\section{Triple-loop analysis on governance and stakeholders' interaction}

\section{Representativeness}

Most of the stakeholders ( 9 of 15, including the members of the agricultural sector and socioenvironmental defenders) considered themselves not represented in El Hondo Natural Park's management. For these stakeholders, 'feeling represented' should be 'to be a referent or a leader', identified by the Natural Park Advisory Board and the Carrizales irrigation community and Agricultural Natural Park, but also 'being part and influencing in decision-making processes', as highlighted by the Segura River Basin Authority and both city councils (Elche and Crevillente). The frustration of feeling unrepresented in El Hondo Natural Park's management were polarized on a conflict of interests and the lack of political will (confirmed by the socioenvironmental defenders). However, some members of the agricultural sector, as the Riegos de Levante Left Margin irrigation community, considered that the lack of recognition as experts able to address environmental issues (just like the local ecological groups) was also a reason. This result could support the lack of cross-sectoral and multifunctional acknowledgment and of a common strategy identified by the stakeholders when asking about the participation rules in the current management of El Hondo Natural Park.

\section{Relevance}

The overall stakeholders' self-value in El Hondo Natural Park's management was high, with a range between 4 


\begin{tabular}{|c|c|c|c|c|c|c|c|c|}
\hline \multirow{3}{*}{$\begin{array}{l}\text { Stakeholder } \\
\text { Segura River Basin Authority }\end{array}$} & \multicolumn{3}{|c|}{ Valuing importance (role and functions) } & \multicolumn{3}{|c|}{ Valuing support (actions) } & \multicolumn{2}{|c|}{$\begin{array}{l}\text { Importance (theory) vs } \\
\text { Support (practice) }\end{array}$} \\
\hline & Own value & \multirow{2}{*}{$\begin{array}{r}\text { External value } \\
4,4 \\
\end{array}$} & Own vs external & Own value & External value & Own vs external & Own value & External value \\
\hline & 5 & & $-0,6$ & 3 & 1,9 & $-1,1$ & -2 & $-2,5$ \\
\hline Natural Park Advisory Board & 5 & 4,1 & $-0,9$ & 4 & 3,2 & $-0,8$ & -1 & $-0,9$ \\
\hline Elche city council & 5 & 3,9 & $-1,1$ & 4 & 2,4 & $-1,6$ & -1 & -1.5 \\
\hline Crevillente city council & 3 & 4,1 & 1,1 & 3 & 2,5 & $-0,5$ & 0 & $-1,6$ \\
\hline Riegos de Levante Left Margin irrigation community & 5 & 4,7 & $-0,3$ & 3 & 3,1 & 0,1 & -2 & $-1,6$ \\
\hline Carrizales irrigation community and Agricultural Natural Park & 5 & 4,3 & $-0,7$ & 3 & 3,6 & 0,6 & -2 & $-0,7$ \\
\hline Young Farmers Agrarian Association & 3 & 3,1 & 0,1 & 4 & 1,7 & $-2,3$ & 1 & $-1,4$ \\
\hline Union of Farmers and Livestock & 4 & 3,1 & -0.9 & 3 & 1,9 & $-1,1$ & -1 & -1.2 \\
\hline SEO-BirdLife & 4 & 3,9 & $-0,1$ & 4 & 2,5 & $-1,5$ & 0 & $-1,4$ \\
\hline Southeast Naturalists Association & 3 & 3,9 & 0,9 & 3 & 3,2 & 0,2 & 0 & $-0,7$ \\
\hline Friends of the Wetlands of the South of Alicante & 4 & 3,6 & $-0,4$ & 3 & 3,0 & 0,0 & -1 & $-0,6$ \\
\hline Local Action Group Sur de Alicante & 5 & 3,7 & $-1,3$ & 5 & 2,9 & $-2,1$ & 0 & $-0,8$ \\
\hline Vinalopó Observatory & 4 & 2,6 & $-1,4$ & 3 & 2,2 & -0.8 & -1 & -0.4 \\
\hline Rural Development of the Camp d'Elx Association & 3. & 3,3 & 0,3 & 3 & 2,9 & $-0,1$ & 0 & -0.4 \\
\hline Sustainable Development of Protected Natural Spaces Association & 2 & 3,2 & 1,2 & 2 & 2,8 & 0,8 & 0 & $-0,4$ \\
\hline
\end{tabular}

Fig. 3 Contrasted own and external value regarding the importance and support of each actor

(necessary role) and 5 (essential role). Those stakeholders who have received the best external rate to support their role were the Riegos de Levante Left Margin irrigation community, followed by the Segura River Basin Authority, Carrizales irrigation community and Agricultural Natural Park, and the Natural Park Advisory Board. These stakeholders are also considered the most relevant in decision-making processes, that is, those with more capacity and power to impose their interests. On the contrary, the Vinalopó Observatory and both union farms have been the lowest-rated (Fig. 3). Comparing self and external values regarding stakeholders' roles, both irrigation communities (Riegos de Levante Left Margin and Carrizales) and two social movements (Vinalopó Observatory and Local Action Group Sur de Alicante) have received better scores than their own rating. Moreover, the best external rate based on those actions carried out by each actor was for Carrizales irrigation community and Agricultural Natural Park, followed by the Natural Park Advisory Board and the Southeast Naturalists Association. In contrast, the lowest external rate has been received by both union farms and the Segura River Basin Authority.

Comparing self and external rates according to roles and functions, and actions, some highlights could be shared: (1) Government officials and the agricultural sector tend to value themselves worse in practice (actions) than in theory (roles and functions), while socioenvironmental defenders offered similar values in both cases; (2) Only two stakeholders (Southeast Naturalists Association and Sustainable Development of Protected Natural Spaces Association) received a better external score in both roles and functions, and actions; and (3) All the stakeholders were less valued for their actions than for their roles and functions, where the greatest difference between both values do not follow a pattern differentiated by groups of stakeholders, including government officials (the Segura River Basin Authority, Elche city council), the agricultural sector (Riegos de
Levante Left Margin irrigation community and both union farms) and socioenvironmental defenders (SEO-BirdLife).

\section{Collaboration}

Except for the Natural Park Advisory Board, stakeholders considered that the main precondition for formulating agreements was willingness or predisposition to collaborate, although some socioenvironmental defenders considered the affinity between stakeholders according to compatible discourses. It is interesting to note that there is no sharp difference between the agricultural sector's choices and the ones of socioenvironmental defenders.

Regarding the type of agreement, signed agreements and joint statements have been considered the best mechanisms to fix the collaboration between stakeholders. However, the Segura River Basin Authority, the Rural Development of the Camp d'Elx Association, and the Elche city council also accepted verbal agreements. Furthermore, stakeholders identified the main reasons explaining the lack of agreement: the incompatibility of interests and the lack of willingness to collaborate with, although stakeholders' unequal levels of recognition as experts is considered, as confirmed by socioenvironmental defenders. Although in this type of question, stakeholders tend to be politically correct by displaying a proactive attitude to establish future agreements with any actor (even if they are involved in a conflict), some stakeholders from social movements refused to promote agreements with those stakeholders who have been negatively considered for their actions (e.g., the Segura River Basin Authority, both union farms, and the Vinalopó Observatory). 


\section{Discussion}

Coastal wetlands are often challenged by overlapping water interests, mainly concerning preservation and economic activities, such as agriculture. However, insufficient attention has been paid to the specific driving factors that could explain the conflicting narratives between agriculture and conservation coexistence (Bockstael et al. 2016). This study provided a test from the coastal wetland of El Hondo Natural Park to advance in stakeholders' narratives and behaviour comprehension regarding those factors influencing decisionmaking processes: (1) the origin and evolution of the socioecological system, (2) the provision of ecosystem services, (3) those strategies to address water scarcity and water quality standards, (4) the management of public and private investment, and (5) the benefits obtained when a coastal wetland is declared as a natural park. Likewise, results from stakeholders' interactions based on the analysis of their level of representativeness and mutual recognition, their relevance in decision-making processes, and their collaboration capacity through agreements have been useful to provide complementary information to identify power (im)balance when addressing water management and governance.

The consideration of power (im)balance can be related to the complexity of managing water interests, even more, water rights, both individual and collective, as a recurrently discussed issue in most coastal wetlands when they are contemplated as common-property systems (Boelens and Claudín 2015). In this sense, El Hondo Natural Park is not an isolated case. Less than $200 \mathrm{~km}$ north-est, a very similar situation can be found: Valencia's Albufera Natural Park, in which individual and collective water interests and water rights coexist. According to Jégou and Sanchis-Ibor (2019), when individual and collective rights (aims to) coexist, a reformulation of the institutional management architecture (e.g., an advisory board) is required to ensure transparency, conciliation, and shared governance. In this sense, the results obtained in El Hondo Natural Park confirmed that the Natural Park Advisory Board has been useful to improve coastal wetland conservation and increase environmental awareness. However, it was insufficient to reduce power imbalance in the decision-making process nor increase mutual recognition among stakeholders (especially between the Riegos de Levante Left Margin irrigation community and most socioenvironmental defenders). This limited capacity when managing the socio-ecological system as an hydrosocial territory can be conditioned by the socio-economic progress and the socio-environmental justice narratives' incompatibility, as suggested by some stakeholders (e.g., Vinalopó Observatory, Sustainable Development of Protected Natural Spaces Association). Authors such as Hulshof and Vos (2016) specifically address this issue in Valencia's Albufera to conclude that these dual narratives are divergent realities, reframing both concepts as the agronomic waterscape frame (dominated by individual rights) and the idyllic waterscape frame (related to collective rights).

Results also highlighted three main learnings from stakeholders' perception and mutual understanding. Firstly, conflicting interests and lack of political will to ensure stakeholders' participation increase stakeholders' feelings of underrepresentation and motivated power imbalance, especially among socioenvironmental defenders (local ecologist groups and social movements). Secondly, stakeholders' actions are less valued than stakeholders' roles and functions, especially those with greater decision-making power (regional government and irrigation communities). Finally, agreements among stakeholders are based on the predisposition to collaborate and the affinity or mutual recognition (especially regarding socioenvironmental defenders) but are restricted by the private property rules and environmental regulation nexus. This last point fits well with previous studies in which agreements in coastal wetlands tend to be dismissed when the legal right of private property is more relevant than the environmental regulation (MojicaVélez et al. 2018). However, agreements and collaboration between stakeholders tend to occur when participation rules and mechanisms of dialogue are clear and well established according to constant interaction and predisposition among stakeholders (Harrington 2017; Silverman et al. 2020; Maczka et al. 2021; Qi et al. 2021). How to address this gap in which stakeholders' involvement is not enough to avoid conflict and power imbalance?

In the last two decades, there has been an increasing number of initiatives for the management of coastal wetlands based on governance and participatory approaches, which are rooted in active commitment and stakeholders' collaboration to face oncoming challenges, such as climate change impacts on water resources and biodiversity (Newaz and Rahman 2019; Shipman et al. 2020). Although there is no unified model nor policy for efficient coastal wetland governance, some scholars considered polycentric governance useful to address conflict resolution due to the combination of innovation, social-learning, adaptation capacity, trustworthiness, and levels of cooperation among stakeholders (Ostrom 2010; Heikkila et al. 2018). This approach involves multiple (semi)independent centres of decision-making that take each other into account through specific interactions and relationships among stakeholders (Carlisle and Gruby 2019). More than as an alternative governance model, polycentricity should be used to study the site and timespecific factors that influence management and governance. Based on the obtained results, future research could apply the polycentric governance approach to check how different centres of decision-making can reduce the conflict between conservation and agriculture narratives by focusing on local 
contexts dynamics and particularities (Baldwin et al. 2018; Kellner et al. 2019).

For example, the results obtained in the JS index focused on the similarity among stakeholders' narratives could be used as the starting point to identify which independent centres of decision-making could be promoted in combination with the five driving factors motivating conflict. Furthermore, independent decision-making centres can be organized according to the triple-loop analysis of governance (representativeness, relevance, and collaboration) to deal with each issue separately and avoid bilateral stakeholders' confrontations. This proposal fits well with the establishment of wetland contracts (Horvat and Smrekar 2021), similarly to the consolidated river contracts in which stakeholders' participation is promoted to reduce the underrepresentation or underrecognition of stakeholders in decision-making processes to finally build a 'technical desk' for the locally conducted action strategies (Bocchi et al. 2012). In this sense, the triple-loop analysis used in this study can complement this 'technical desk' by deepening the 'social' side of the management of socio-ecological systems by highlighting the reasons why the participation process is complex but also how this complexity could be analyzed in a simplified way to increase stakeholders' motivation to be involved in decision-making process (Okumah et al. 2020). Furthermore, this approach could provide an updated framework combining conceptual and methodological issues with fixing main stakeholders' roles (to be), actions (to do) and alliances (to share) in a replicable, integrated and non-static way according to the spatial and temporal dynamics that characterize these hybrid spaces.

\section{Conclusion}

Agriculture and conservation can be compatible in a coastal wetland, but it requires attention to the specific driving factors explaining the co-existing and conflicting narratives influencing decision-making processes.

The study of El Hondo Natural Park identified five main driving factors to be considered: (1) the origin and evolution of the coastal wetland, (2) the provision and value of ecosystem services, (3) the management of water scarcity and water quality standards, (4) the guarantee and management of public and private investment, and (5) consequences of a natural park declaration. When addressing these issues, stakeholders' behaviours differed in representativeness, relevance, and collaboration levels, providing examples of underrepresentation and power imbalance and negative assessments regarding stakeholders' actions. However, results also highlighted some experiences of predisposition to establish agreements and stakeholders' mutual comprehension and affinity. In order to deepen these learnings, further research should be focused on (1) customizing conflicted narratives and power (im)balance interactions in a systematic way, (2) rethinking the role of conflict in hydrosocial territories and how conflicts can become part of stakeholder identities, and (3) exploring the productive power of such conflicts as catalysts when facing current and potential socioeconomic and environmental challenges.

Acknowledgements We would want to thank you stakeholders for their collaboration in providing their experience and time.

Funding Open Access funding provided thanks to the CRUE-CSIC agreement with Springer Nature. This study were funded by Ministerio de Economía y Competitividad (FJCI-2015-24346) and University of Alicante (I-PI-88-18).

Open Access This article is licensed under a Creative Commons Attribution 4.0 International License, which permits use, sharing, adaptation, distribution and reproduction in any medium or format, as long as you give appropriate credit to the original author(s) and the source, provide a link to the Creative Commons licence, and indicate if changes were made. The images or other third party material in this article are included in the article's Creative Commons licence, unless indicated otherwise in a credit line to the material. If material is not included in the article's Creative Commons licence and your intended use is not permitted by statutory regulation or exceeds the permitted use, you will need to obtain permission directly from the copyright holder. To view a copy of this licence, visit http://creativecommons.org/licenses/by/4.0/.

\section{References}

Al-Anazi, S., H. Al-Mahmoud, and I. Al-Turaiki. 2016. Finding similar documents using different clustering techniques. Procedia Computer Science 82: 28-34.

Baldwin, E., P. McCord, J. Dell'Angelo, and T. Evans. 2018. Collective action in a polycentric water governance system. Environmental Policy and Governance 28 (4): 212-222.

Bocchi, S., D. La Rosa, and P. Pileri. 2012. Agro-ecological analysis for the EU water framework directive: An applied case study for the river contract of the Seveso Basin (Italy). Environmental Management 50: 514-529.

Bockstael, E., N.C.F. Bahia, C.S. Seixas, and F. Berkes. 2016. Participation in protected area management planning in coastal Brazil. Environmental Science and Policy 60: 1-10.

Boelens, R., and V. Claudín. 2015. Rooted rights systems in turbulent water: The dynamics of collective fishing rights in La Albufera, Valencia, Spain. Society and Natural Resources 28 (10): 1059-1074.

Boelens, R., J. Hoogesteger, E. Swyngedouw, J. Vos, and P. Wester. 2016. Hydrosocial territories: A political ecology perspective. Water International 41 (1): 1-14.

Bryson, J.M. 2004. What to do when stakeholders matter. Public Management Review 6 (1): 21-53.

Campbell, R., R. Goodman-Williams, H. Feeney, and G. Fehler-Cabral. 2020. Assessing triangulation across methodologies, methods, and stakeholder groups: The joys, woes, and politics of interpreting convergent and divergent data. American Journal of Evaluation 41 (1): $125-144$. 
Canales, G., J.A. Segrelles, and M.I. Vera. 2012. El capital social en el entorno de los espacios naturales protegidos de El Hondo y de las lagunas de la Mata y Torrevieja. In Capital social en espacios naturales protegidos de España, ed. C. Foronda, 171-213. Navarra, Spain: Ulzama Digital.

Carlisle, K., and R.L. Gruby. 2019. Polycentric systems of governance: A theoretical model for the commons. Policy Studies Journal 47 (4): 927-952.

Colvin, R.M., G.B. Witt, and J. Lacey. 2016. Approaches to identifying stakeholders in environmental management: Insights from practitioners to go beyond the 'usual suspects.' Land Use Policy 52: $266-276$

Colvin, R.M., G.B. Witt, and J. Lacey. 2020. Power, perspective, and privilege: The challenge of translating stakeholder theory from business management to environmental and nature resource management. Journal of Environmental Management 271: 110974.

Costanza, R., R. de Groot, P. Sutton, S. van der Ploeg, S.J. Anderson, I. Kubiszewski, S. Farber, and R.K. Turner. 2014. Changes in the global value of ecosystem services. Global Environmental Change 26: 152-158.

Craft, C., V. Jan, and L. Kropfelova. 2018. Carbon sequestration and nutrient accumulation in floodplain and depression wetlands. Ecological Engineering 114: 137-145.

Davidson, N.C. 2014. How much wetland has the world lost? Longterm and recent trends in global wetland area. Marine and Freshwater Research 65: 934-941.

Everard, M. 2019. A socio-ecological framework supporting catchment-scale water resource stewardship. Environmental Science and Policy 91: 50-59.

FAO. 2008. Scoping agriculture-wetland interactions. Towards a sustainable multiple-response strategy. FAO water Reports 33, Rome. http://www.fao.org/3/i0314e/i0314e.pdf. Accessed 12 March 2021.

Fennessy, S., and C. Craft. 2011. Agricultural conservation practices increase wetland ecosystem services in the Glaciated Interior Plains. Ecological Application 21 (1): 49-64.

Ferguson, L., S. Chan, M. Santelmann, and B. Tilt. 2017. Exploring participant motivations and expectations in a researcher-stakeholder engagement process: Willamete water 2100. Landscape and Urban Planning 157: 447-456.

Fisher, J., H. Stutzman, M. Vedoveto, D. Delgado, R. Rivero, W.Q. Dariquebe, L.S. Contraras, T. Souto, A. Harden, and S. Rhee. 2020. Collaborative governance and conflict management: Lessons learned and good practices from a case study in the Amazon basin. Society and Natural Resources 33 (4): 538-553.

Garcia, X., M. Benages-Albert, M. Buchecker, and P. Vall-Casas. 2020. River rehabilitation: Preference factors and public participation implications. Journal of Environmental Planning and Management 63 (9): 1528-1549.

Godden, L., and R. Ison. 2019. Community participation: Exploring legitimacy in socio-ecological systems for environmental water governance. Australasian Journal of Water Resources 23 (1): $45-57$.

Guaita-García, N., J. Martinez-Fernandez, C.J. Barrera-Causil, M.A. Esteve-Selma, and H.C. Fitz. 2021. Local perceptions regarding a socio-ecological system of the Mediterranean coast: The Mar Menor (Region de Murcia, Spain). Environment, Development and Sustainability 23: 2882-2909.

Harrington, C. 2017. The political ontology of collaborative water governance. Water International 42 (3): 254-270.

Heikkila, T., S. Villamayor-Tomas, and D. Garrick. 2018. Bringing polycentric systems into focus for environmental governance. Environmental Policy and Governance 28 (4): 207-211.

Hopkins, K.G., G.B. Noe, F. Franco, E.J. Pindilli, S. Gordon, M.J. Metes, P.R. Claggett, A.C. Gellis, C.R. Hupp, and D.M. Hogan. 2018. A method to quantify and value floodplain sediment and nutrient retention ecosystem services. Journal of Environmental Management 220: 65-76.

Horvat, K.P., and A. Smrekar. 2021. The wetland contract as a tool for successful wetland governance: A case study of Ljubljansko Barje Nature Park, Slovenia. Sustainability 13: 425.

Hulshof, M., and J. Vos. 2016. Diverging realities: How framing, values and water management are interwoven in the Albufera de Valencia wetland in Spain. Water International 41 (1): 107-124.

Janse, J.H., A.A. van Dam, E.M.A. Hes, J.J.M. de Klein, C.M. Finlayson, A.B.G. Janssen, D. van Wijk, W.M. Mooij, and J.T.A. Verhoeven. 2019. Towards a global model for wetlands ecosystem services. Current Opinion in Environmental Sustainability 36: 11-19.

Jégou, A., and C. Sanchis-Ibor. 2019. The opaque lagoon. Water management and governance in l'Albufera de Valéncia wetland (Spain). Limnetica 38 (1): 503-515.

Junk, W.J., S. An, C.M. Finlayson, B. Gopal, J. Kvet, S.A. Mitchell, W.J. Mitsch, and R.D. Robarts. 2013. Current state of knowledge regarding the world's wetlands and their future under global climate change: A synthesis. Aquatic Sciences 75: 151-167.

Kellner, E., C. Oberlack, and J.D. Gerber. 2019. Polycentric governance compensates for incoherence of resource regimes: The case of water uses under climate change in Oberhasli, Switzerland. Environmental Science and Policy 100: 126-135.

Kingsford, R.T., A. Basset, and L. Jackson. 2016. Wetlands: Conservation's poor cousins. Aquatic Conservation: Marine and Freshwater Ecosystems 26 (5): 892-916.

Li, X., R. Bellerby, C. Craft, and S.E. Widney. 2018. Coastal wetlands loss, consequences, and challenges for restauration. Anthropocene Coasts 1 (1): 1-15.

Lienert, J., F. Schnetzer, and K. Ingold. 2013. Stakeholder analysis combined with social network analysis provides fine-grained insights into water infrastructure planning processes. Journal of Environmental Management 125: 134-148.

Linton, J., and J. Budds. 2014. The hydrosocial cycle: Defining and mobilizing a relational-dialectical approach to water. Geoforum 57: $170-180$.

Lombard, M., and C. Rakodi. 2016. Urban land conflict in the Global South: Towards an analytical framework. Urban Studies 53 (13): 2683-2699.

López-Pomares, A., G.M. López-Iborra, and C. Martín-Cantarino. 2009. Influence of characteristics of irrigation channels on the breeding bird community of a wetland zone in Southeast of Spain. In Sustainable management of Mediterranean coastal fresh and transitional water bodies: A socio-economic and environmental analysis of changes and trends to enhance and sustain stakeholder benefits, ed. F. Scapini, J-M. Boffa, L.F. Cassar, E. Conrad, and M. Nardi, 1-5. Firenze, Italy: University Press.

Lunenburg, F.C. 2012. Power and leadership: An influence process. International Journal of Management, Business, and Administration 15 (1): 1-9.

Maczka, K., P. Matczak, A. Jeran, P.J. Chmielewski, and S. Baker. 2021. Conflicts on ecosystem services management: Analysis of stakeholder participation in Natura 2000 in Poland. Environmental Science and Policy 117: 16-24.

Manosalvas, R., J. Hoogesteger, and R. Boelens. 2021. Contractual reciprocity and the re-making of community hydrosocial territories: The case of La Chimba in the Ecuadorian páramos. Water 13 (11): 1600

Martín-Cantarino, C. 2009. Environmental conflicts and conflict management: Some lessons from the WADI experience at El Hondo Nature Park (South-Eastern Spain). In Coastal water bodies: Nature and culture conflicts in the Mediterranean, ed. F. Scapini and G. Ciampi, 61-77. New York: Springer. 
Melgarejo-Moreno, J., A. Molina-Giménez, and P. Fernández-Aracil. 2018. 100 años de Riegos de Levante, izquierda del Segura. Alacant, Spain: Universitat d'Alacant.

Mojica-Vélez, J.M., S. Barrassa-Garcia, and A. Espinoza-Tenorio. 2018. Policies in coastal wetlands: Key challenges. Environmental Science and Policy 88: 72-82.

Natow, R.S. 2020. The use of triangulation in qualitative studies employing elite interviews. Qualitative Research 20 (2): 160-173.

Newaz, M.W., and S. Rahman. 2019. Wetland resource governance in Bangladesh: An analysis of community-based co-management approach. Environmental Development 32: 100446.

Okumah, M., A.S. Yeboah, and O. Amponsah. 2020. Stakeholders' willingness and motivations to support sustainable resources management: Insights from a Ghanaian study. Conservation Science and Practice 2 (3): e170.

Ostrom, E. 2010. Polycentric systems for coping with collective action and global environmental change. Global Environmental Change 20: 550-557.

Pahl-Wostl, C., C. Knieper, E. Lukat, F. Meergans, M. Schoderer, N. Schütze, D. Schweigatz, I. Dombrowsky, A. Lenschow, U. Stein, A. Thiel, J. Troltzsch, and R. Vidaurre. 2020. Enhancing the capacity of water governance to deal with complex management challenges: A framework for analysis. Environmental Science and Policy 107: 23-35.

Prieto-López, A., B. Duarte-Abadía, and R. Boelens. 2021. Territory in conflict: Land dispossession, water grabbing and mobilization for environmental justice in southern Spain. International Journal of Water Resources Development. https://doi.org/10.1080/07900 627.2020 .1854693$.

Qi, D., Z. Si, and S. Scott. 2021. Can we be more collaborative? Topdown policies and urban-rural divides in the ecological agriculture sector in Nanjing, China. Society and Natural Resources 34 (2): 208-226.

Ragavan, P., K. Kathiresan, P.M. Mohan, K. Ravichandran, R.S.C. Jayaraj, and T.S. Rana. 2020. Ensuring the adaptive potential of coastal wetlands of India - the need of the hour for sustainable management. Wetlands Ecology and Management. https://doi.org/ 10.1007/s11273-020-09742-Z.

Rambaree, K., A. Sundstrom, Z. Wang, and S.A.I. Wright. 2021. Qualitative stakeholder analysis for a Swedish regional biogas development: A thematic network approach. Sustainability 13 (4): 8003.

Ramsar Convention Secretariat. 2010. Managing wetlands: Frameworks for managing Wetlands of International Importance and other wetland sites. Ramsar handbooks for the wise use of wetlands, 4th edition, vol. 18. https://www.ramsar.org/sites/default/ files/documents/pdf/lib/hbk4-18.pdf. Accessed 24 April 2021.

Reed, M.S., A. Graves, N. Dandy, H. Posthumus, K. Hubacek, J. Morris, C. Prell, C.H. Quinn, and L.C. Stringer. 2009. Who's in and why? A typology of stakeholder analysis methods for natural resource management. Journal of Environmental Management 90 (5): 1933-1949.

Ricart, S. 2020. Water governance and social learning: Approaches, tools and challenges. In Clean Water and Sanitation, Encyclopedia of the UN Sustainable Development Goals, ed. W. Leal Filho, A.M. Azul, L. Brandli, A. Lange Salvia, and T. Wall. Cham, Switzerland: Springer Nature.

Ricart, S., and C. Gandolfi. 2017. Balancing irrigation multifunctionality based on key stakeholders' attitudes: Lessons learned from the Muzza system, Italy. Land Use Policy 69: 461-473.

Ricart, S., A.M. Rico, N. Kirk, F. Bülow, A. Ribas-Palom, and D. Pavón. 2019. How to improve water governance in multifunctional irrigation systems? Balancing stakeholder engagement in hydrosocial territories. International Journal of Water Resources Development 35 (3): 491-524.

Ruiz, C. 2014. Valoración económica de los parques naturales del sur de la provincia de Alicante. PhD dissertation, Department of Agri-environmental Economics. Elche, Spain: Universidad Miguel Hernández.

Ruiz-Villaverde, A., and M.A. García-Rubio. 2017. Public participation in European water management: From theory to practice. Water Resources Management 31 (8): 2479-2495.

Scheidel, A., D. Del Bene, J. Liu, G. Navas, S. Mingorria, F. Demaria, S. Avila, B. Roy, I. Ertor, L. Temper, and J. Martinez-Alier. 2020. Environmental conflicts and defenders: A global overview. Global Environmental Change 63: 102104.

Schmidt, J.J. 2014. Historicising the hydrosocial cycle. Water Alternatives 7 (1): 220-234.

Scott, T.A., N. Ulibarri, and R.P. Scott. 2020. Stakeholder involvement in collaborative regulatory processes: Using automated coding to track attendance and actions. Regulation and Governance 14: 219-237.

Shah, E., J. Vos, G.J. Veldwisch, R. Boelens, and B. Duarte-Abadia. 2021. Environmental justice movements in globalising networks: A critical discussion on social resistance against large dams. The Journal of Peasant Studies 48 (5): 1008-1032.

Shipman, B., and Ž. Rajković. 2020. The governance of coastal wetlands in the Mediterranean - A Handbook. Split (Croatia): Regional Activity Centre PAP/RAC.

Silber-Coats, N. 2017. Clean energy and water conflicts: Contested narratives of small hydropower in Mexico's Sierra Madre Oriental. Water Alternatives 10 (2): 578-601.

Silverman, R.M., H.L. Taylor, L. Yin, C. Miller, and P. Buggs. 2020. Are we still going through the empty ritual of participation? Innercity residents and other grassroots stakeholders' perceptions of public input and neighbourhood revitalization. Critical Sociology 46 (3): 413-428.

Speake, M.A., M.E. Carbone, and C.V. Spetter. 2020. Análisis del sistema socio-ecológico del estuario Bahía Blanca (Argentina) y su impacto en los servicios ecosistémicos y el bienestar humano. Investigaciones Geograficas 73: 121-145.

Stepanova, O., M. Polk, and H. Saldert. 2020. Understanding mechanisms of conflict resolution beyond collaboration: An interdisciplinary typology of knowledge types and their integration in practice. Sustainability Science 15: 263-279.

Svarstad, H., and T.A. Benjaminsen. 2020. Reading radical environmental justice through a political ecology lends. Geoforum 108: $1-11$.

Verhoeven, J.T.A., and T.L. Setter. 2010. Agricultural use of wetlands: Opportunities and limitations. Annals of Botany 105 (1): 155-163.

Vidal-Giménez, F., and C. Ruiz-Mas. 2020. The valuation of recreational use of wetlands and the impactof the economic crisis. International Journal of Environmental Research and Public Health 17: 3238.

Voyer, M., K. Barclay, A. McIlgorm, and N. Mazur. 2017. Connections or conflict? A social and economic analysis of the interconnections between the professional fishing industry, recreational fishing and maritime tourism in coastal communities in NSW, Australia. Marine Policy 76: 114-121.

Wang, Y., and X. Chen. 2020. River chief system as a collaborative water governance approach in China. International Journal of Water Resources Development 36 (4): 610-630.

Wesselink, A., M. Kooy, and J. Warner. 2016. Socio-hydrology and hydrosocial analysis: Toward dialogues across disciplines. Wires Water 4 (2): e1196.

Wilfong, M., and M. Pavao-Zuckerman. 2020. Rethinking stormwater: Analysis using the hydrosocial cycle. Water 12: 1273.

Woldesenbet, W.G. 2020. Analyzing multi-stakeholder collaborative governance practices in urban water projects in Addis Ababa City: Procedures, priorities and structures. Applied Water Science 10: 44.

Yonariza, B.A., Mahdi Andini, and S. Maynard. 2019. Addressing knowledge gaps between stakeholders in payments for watershed 
services: Case of Koto Panjang hydropower plant catchment area, Sumatra, Indonesia. Ecosystem Services 39: 100995.

Zou, Y., L. Wang, Z. Xue, E. Mingju, M. Jiang, X. Lu, S. Yang, X. Shen, Z. Liu, G. Sun, and X. Yu. 2018. Impacts of agricultural and reclamation practices on wetlands in the Amur River Basin, Northeastern China. Wetlands 38: 383-389.

Publisher's Note Springer Nature remains neutral with regard to jurisdictional claims in published maps and institutional affiliations.

Sandra Ricart is a human-environment geographer interested in modelling coupled human-nature systems interdependencies from sociallearning and stakeholder behaviour analysis. She received his Ph.D. in Experimental Sciences and Sustainability in 2014 at the University of Girona, Spain. She is currently a Marie Sklodowska-Curie Action IF post-doctoral researcher at the Environmental Intelligence Lab at the Politecnico di Milano, Italy. Since 2017 she also collaborates with the
Interuniversity Institute of Geography at the University of Alicante, as researcher in several projects, lecturer at the Masters in Planning and Management of Natural Risks and as coordinator and professor of a MOOC on natural risks analysis. She was visiting researcher at different universities in France, Italy and The Netherlands and she published about 30 articles in JCR and Scopus journals.

Antonio M. Rico-Amorós is a Full Professor at the Department of Regional Geographic Analysis and Physical Geography and the Masters in Planning and Management of Natural Risks at the University of Alicante, Spain. He is the Director of the Interuniversity Institute of Geography at the same university, being the Editor-in-Chief of the journal Investigaciones Geográficas, indexed in the Scopus database. He is a transdisciplinary researcher with more than 120 publications indexed in JCR and Scopus databases focused on agricultural and urban-tourist water use management, rural development and land planning, and climatic risks (droughts and floods) and adaptation strategies in semi-arid regions. He participated in more than 30 competitive research projects at regional, national, and European contexts, being PI in most of them. 